\title{
Pengaruh Model Pembelajaran Role Playing Berbasis Tri Hita Karana Terhadap Kompetensi Pengetahuan IPS Siswa Kelas IV SD Gugus Untung Surapati
}

\author{
I Gede Widnyana ${ }^{1 *}$, I Wayan Sujana², I Ketut Adnyana Putra ${ }^{3}$ \\ ${ }^{123}$ Jurusan Pendidikan Guru Sekolah Dasar (PGSD), Universitas Pendidikan Ganesha, Singaraja, Indonesia.
}

\section{A R T I C L E I N F O}

Article history:

Received 22 November

2017

Received in revised form

18 Desember 2017

Accepted 13 Januari 2018

Available online 20

Februari 2017

Kata Kunci:
role playing, Tri Hita
Karana, kompetensi
pengetahuan IPS
Keywords:
role playing, Tri Hita
Karana, IPS knowledge
competence

\begin{abstract}
A B S T R A K
Penelitian ini bertujuan untuk mengetahui perbedaan yang signifikan kompetensi pengetahuan IPS kelompok siswa yang dibelajarkan dengan model pembelajaran role playing berbasis Tri Hita Karana. Jenis penelitian ini adalah penelitian eksperimen semu dengan rencangan nonequivalent control group design. Sampel diambil dengan teknik random sampling. Sampel dalam penelitian ini adalah siswa kelas IV SDN 6 Sumerta berjumlah 39 siswa sebagai kelompok yang dibelajarankan dengan model pembelajaran role playing berbasis Tri Hita Karana dan siswa kelas IV SDN 11 Sumerta berjumlah 38 orang siswa sebagai kelompok kontrol dengan pembelajaran konvensional. Pengumpulan data dilakukan dengan menggunakan metode tes dalam bentuk tes objektif pilihan ganda biasa dengan empat pilihan jawaban. Data yang diperoleh dianalisis menggunakan analisis uji-t. Hasil analisis data diperoleh thitung $=8,315>$ ttabel $=2,000$ untuk signifikansi $5 \%$ dan $\mathrm{dk}=75$. Berdasarkan kriteria pengujian, maka $\mathrm{HO}$ ditolak. Adapun nilai rata-rata kompetensi pengetahuan IPS pada kelompok yang dibelajarkan dengan model pembelajaran role playing berbasis Tri Hita
\end{abstract} Karana adalah $X=84,31$, sedangkan pada kelompok yang dibelajarankan dengan pembelajaran konvensional adalah $\mathrm{X}=69,11$. Berdasarkan hasil penelitian tersebut dapat disimpulkan bahwa terdapat pengaruh model pembelajaran role playing berbasis Tri Hita Karana terhadap kompetensi pengetahuan IPS siswa kelas IV SD Gugus Untung Surapati Kecamatan Denpasar Timur Tahun Pelajaran 2016/2017.

\section{A B S T R A C T}

This research aims to determine the significant differences in the competence of IPS group knowledge of students who are taught by role playing learning model based on Tri Hita Karana. This research type is quasi experiment research with nonequivalent control group design. Samples were taken by random sampling technique. The sample in this research is the fourth grade students of SDN 6 Sumerta amounting to 39 students as the group which is recommended with the role playing model based on Tri Hita Karana and the fourth grade students of SDN 11 Sumerta are 38 students as control group with conventional learning. The data collection is done by using the test method in the form of the usual double choice objective test with four answers. The data obtained were analyzed using t-test analysis. The result of data analysis is tvalue $=8,315>$ ttable $=2,000$ for $5 \%$ significance and $\mathrm{dk}=75$. Based on test criteria, $\mathrm{HO}$ is rejected. The average score of IPS knowledge competence in the group that was studied with the role playing model based on Tri Hita Karana was $X=84,31$, while in the group recommended with conventional learning was $X=69,11$. Based on the result of this research, it can be concluded that there is influence of role playing model based on Tri Hita Karana on the competence of IPS knowledge of fourth grade students of SD Untung Surapati Unit, Denpasara Timur Sub District, Lesson Year 2016/2017. concluded that the model of learning group investigastion affect learning outcomes Civics class VI students of SD N 2 Datah regency of Karangasem.

Copyright (C) Universitas Pendidikan Ganesha. All rights reserved.

\footnotetext{
* Corresponding author.

E-mail addresses: gedewidnyana75@gmail.com (I Gede Widnyana)
} 


\section{Pendahuluan}

Berbagai upaya perbaikan terus dilakukan oleh pemerintah untuk meningkatkan mutu pendidikan. Upaya-upaya perbaikan yang dilakukan pemerintah antara lain penyempurnaan kurikulum, penyedian sarana dan prasarana pendidikan, penyelenggaraan pelatihan dan memberikan kesempatan beasiswa bagi guru-guru untuk melanjutkan studi ke jenjang pendidikan yang lebih tinggi serta adanya program kelompok kerja kepala sekolah (K3S) seperti mendiskusikan tentang administrasi guru, menyusun tes akhir semester, sosialisasi melalui seminar atau lokakarya pembelajaran, dan sebagainya. Berbagai upaya telah dilakukan belum memberikan hasil yang optimal dalam meningkatkan mutu pendidikan.

Perubahan kurikulum, dari kurikulum 2004 yang lebih dikenal dengan kurikulum berbasis kompetensi (KBK) menjadi kurikulum 2006 atau yang sering disebut dengan kurikulum tingkat satuan pendidikan (KTSP) salah satu upaya pemerintah untuk mengatasi rendahnya kualitas pendidikan. Kurikulum 2006 sebenarnya tidak jauh berbeda dengan kurikulum 2004, yang sama-sama menuntut adanya perubahan dari proses pembelajaran yang cendrung pasif, teoritis, dan berpusat pada guru ke proses pembelajaran yang bersifat aktif, kreaktif dan produktif, mengacu pada permasalahan nyata dan berpusat pada siswa, karena itu, penilaian hasil belajar dalam pelaksanaan KTSP perlu dilakukan berdasarkan atas informasi yang selengkap mungkin mengenai siswa yang bersangkutan, agar maksud tersebut terlaksana. Dari pelaksanaan di lapangan mengenai kurikulum tahun 2006 yang sering didengungkan kurikulum KTSP belum begitu merata guru-guru yang tahu masalah kurikulum tersebut, hanya beberapa sekolah saja yang baru menerapkan sistem pelaksanaan kurikulum 2006, pemerintah kembali mencetuskan kurikulum yang baru yaitu kurikulum 2013.

Pendidikan merupakan usaha sadar secara berencana yang dilakukan oleh orang dewasa untuk mendewasakan seseorang (peserta didik). Menurut Undang-undang RI Nomor 20 Tahun 2003 tentang Sistem Pendidikan Nasional terutama Bab 1 Pasal 1 mendefinisikan pendidikan sebagai berikut. Pendidikan didefinisikan sebagai usaha sadar dan terencana untuk mewujudkan suasana belajar dan proses belajar agar peserta didik secara aktif mengembangkan potensi dirinya untuk memiliki kekuatan spiritual keagamaan, pengendalian diri, kepribadian, kecerdasan, ahlak mulia serta keterampilan yang diperlukan dirinya, masyarakat, bangsa dan negara.

Seiring perkembangan zaman yang berdampak terhadap perubahan kurikulum, maka proses kualitas pembelajaran perlu ditingkatkan. Kondisi seperti itu dimulai dengan meningkatkan kompetensi guru baik dalam menyampaikan materi pembelajaran, teknik mengajar yang tepat, media pembelajaran, model pembelajaran yang sesuai dengan kebutuhan siswa. Guru yang profesional pada hakekatnya mampu menyampaikan materi pembelajaran dengan tepat sesuai dengan kebutuhan belajar siswa. Untuk mencapai hal tersebut perlu diadakan berbagai pelatihan, penguasaan materi dan wawasan dalam pembelajaran termasuk salah satunya menggunakan model pembelajaran yang tepat. Dalam pembelajaran IPS guru tidak cukup terfokus satu model saja tetapi guru perlu mencoba menerapkan model-model pembelajaran inovatif yang sesuai dengan materi pembelajaran khususnya karena ilmu pengetahuan sosial adalah mata pelajaran yang digunakan sebagai wahana untuk mengembangkan kompetensi pengetahuan berlandaskan Tri Hita Karana yang diwujudkan dalam kehidupan sehari-hari baik sebagai individu maupun sebagai anggota masyarakat.

Pada kenyataannya masih banyak guru menyampaikan materi pembelajaran dengan metode ceramah. Dampak dari kebiasaan pembelajaran menerapkan metode ceramah menyebabkan interaksi pembelajaran menjadi tidak kondusif, membuat siswa menjadi jenuh atau bosan muncullah kekacauan di dalam kelas sehingga kondisi kelas tidak terkontrol, siswa tidak disiplin, dan berpengaruh kompetensi pengetahuannya yang rendah sehingga tujuan pembelajaran tidak tercapai sesuai harapan. Peningkatan kualitas pendidikan tidak lepas dari kualitas guru, peningkatan kualitas guru dapat dilakukan salah satunya dengan menerapkan model pembelajaran role playing. Model pembelajaran role playing berbasis Tri Hita Karana memberikan kemungkinan kepada siswa untuk mengembangkan pengetahunnya melalui berbagai kegiatan bermain peran yang didalamnya ada tujuan, aturan dan edutainment (Huda, 2015:208).

Hasil pengamatan di Gugus Untung Surapati siswa kelas IV rata-rata kompetensi pengetahuannya masih perlu dioptimalkan. Permasalahan yang ditemukan merupakan permasalahan nyata yaitu berkaitan dengan permasalahan yang dialami guru dan siswa pada mata pelajaran IPS.

Kompetensi merupakan sesuatu yang kompleks, yang didalamnya mengandung banyak aspek (ranah). Menurut kurikulum 2013, kompetensi itu mencakup sikap, pengetahuan, dan keterampilan (Kosasih, 2014:14). Pada Kurikulum 2013, ketiga aspek itu dinyatakan di dalam rumusan kompetensi inti dengan menggunakan notasi sebagai berikut. (1) Kompetensi Inti 1 (KI-1) untuk kompetensi inti sikap spiritual. (2) Kompetensi Inti 2 (KI-2) untuk kompetensi inti sikap sosial. (3) Kompetensi Inti 3 (KI-3) untuk kompetensi inti pengetahuan. (4) Kompetensi inti 4 (KI-4) untuk kompetensi inti keterampilan. 
Menurut Badan Standar Nasional Pendidikan (BNSP, 2006) dalam Standar Isi untuk Satuan Pendidikan Dasar dinyatakan bahwa kelompok mata pelajaran ilmu pengetahuan dan teknologi pada SD/MI/SDLB dimaksudkan untuk mengenal, menyikapi, dan mengapresiasi ilmu pengetahuan dan teknologi, serta menanamkan kebiasaan berpikir dan berperilaku ilmiah yang kritis, kreatif dan mandiri. Sedangkan menurut Yumarlin (2012) pembelajaran IPS hendaknya mengacu pada pola pengembangan potensi siswa secara optimal melalui pembekalan dan pemberian kesempatan yang luas kepada siswa untuk belajar sehingga mereka mampu mengembangakan pengetahuan, sikap, nilai moral dan keterampilan-keterampilan sosial. Ilmu pengetahuan sosial (IPS) merupakan integrasi dari berbagai cabang ilmu-ilmu sosial dan humaniora, yaitu: sosiologi, sejarah, geografi, ekonomi, politik, hukum dan budaya.

Menurut Susanto (2014:31) mengatakan bahwa secara umum tujuan pembelajaran IPS tingkat SD untuk membekali siswa dalam bidang pengetahuan sosial. Adapun secara khusus tujuan pendidikan IPS di SD adalah sebagai berikut. (1) Pengetahuan sosial yang berguna dalam kehidupannya. (2) Kemampuan mengidentifikasi, menganalisis, dan menyusun alternatif pemecahan masalah nasional yang terjadi dalam kehidupan di masyarakat. (3) Kemampuan berkomunikasi dengan sesama warga masyarakat dan berbagai bidang keilmuan serta bidang keahlian. (4) Kesadaran sikap mental yang positif dan keterampilan terhadap pemanfaatan lingkungan hidup yang menjadi bagian dari kehidupan tersebut. (5) Kemampuan mengembangkan pengetahuan dan keilmuan IPS sesuai dengan perkembangan kehidupan, masyarakat, ilmu pengetahuan dan teknologi.

Model pembelajaran role playing merupakan cara penguasaan bahan-bahan pelajaran melalui pengembangan imajinasi dan penghayatan siswa terhadap materi. Pengembangan imajinasi dan penghayatan dilakukan siswa dengan memerankannya sebagai tokoh hidup atau benda mati. Dalam pelaksanaannya model ini dilakukan lebih dari satu orang, semua bergantung kepada apa yang diperankan. Adapun tujuan model pembelajaran ini adalah untuk menerangkan suatu peristiwa yang di dalamnya menyangkut orang banyak, dan berdasarkan pertimbangan didaktik lebih baik didramatisasikan daripada diceritakan karena akan lebih jelas dan dapat dihayati oleh siswa. Selain itu model ini akan melatih siswa agar mereka mampu menyelesaikan masalah-masalah sosial-psikologis serta dapat melatih siswa agar mereka dapat bergaul dan memberi kemungkinan bagi pemahaman terhadap orang lain beserta masalahnya. (Kurniasih, 2016:68)

Model pembelajaran role playing ini sangat bermanfaat, role playing dapat memberikan semacam hidden practice, dimana murid menggunakan ungkapan-ungkapan terhadap materi yang telah dan sedang mereka pelajari. Kedua, role playing melibatkan jumlah murid yang cukup banyak, cocok untuk kelas besar. Dan selanjutnya, dengan role playing dapat memberikan kepada siswa kesenangan karena role playing pada dasarnya adalah permainan.

Role playing atau bermain peran adalah sejenis permainan gerak yang di dalamnya ada tujuan, aturan, dan edutainment. Dalam role playing, siswa dikondisikan pada situasi tertentu di luar kelas. Selain itu, role playing sering kali dimaksudkan sebagai suatu bentuk aktivitas di mana pembelajar membayangkan dirinya seolah-olah berada di luar kelas dan memainkan peran orang lain. Pada strategi role playing, titik tekannya terletak pada keterlibatan emosional dan pengamatan indra ke dalam suatu situasi permasalahan yang secara nyata dihadapi. Siswa diperlakukan sebagai subjek pembelajaran yang secara aktif melakukan praktek-praktek berbahasa (bertanya dan menjawab) bersama teman-temannya pada situasi tertentu. (Huda, 2015:208).

Masing-masing model pembelajaran mempunyai sintak. Menurut (Huda 2016: 209) sintak model pembelajaran role playing dapat dilihat dalam tahap-tahapnya adalah sebagai berikut. (1) Guru menyusun/menyiapkan skenario yang akan ditampilkan, (2) Guru menunjuk beberapa siswa untuk mempelajari skenario dalam waktu beberapa hari sebelum pelaksanaan kegiatan belajar mengajar, (3) Guru membentuk kelompok siswa yang masing-masing beranggotakan 5 orang, (4) Guru memberikan penjelasan tentang kompetensi yang ingin dicapai, (5) Guru memanggil beberapa siswa yang sudah ditunjuk untuk melakonkan skenario yang sudah dipersiapkan, (6) Masing-masing siswa berada dikelompoknya sambil mengamati skenario yang sedang diperagakan, (7) Setelah selesai ditampilkan, masing-masing siswa diberikan lembar kerja untuk membahas/memberi penilaian atas penampilan masing-masing kelompok, (8) Masing-masing kelompok menyampaikan hasil kesimpulannya, (9) Guru memberikan kesimpulan dan evaluasi secara umum.

Menurut (Kurniasih, 2016:69) adapun kelebihan model pembelajaran role playing ini adalah : (1) Proses pembelajarannya melibatkan seluruh siswa untuk berpartisipasi, (2) Mempunyai kesempatan untuk memajukan kemampuannya dalam bekerja sama, (3) Siswa juga dapat belajar menggunakan bahasa dengan baik dan benar, (3) Siswa bebas mengambil keputusan dan berekspresi secara utuh, (4) Permainan merupakan penemuan yang mudah dan dapat digunakan dalam situasi dan waktu yang berbeda, (5) Guru dapat mengevaluasi pengalaman siswa melalui pengamatan pada waktu melakukan 
permainan, (6) Dapat berkesan dengan kuat dan tahan lama dalam ingatan siswa. Disamping merupakan pengalaman yang menyenangkan yang saling untuk dilupakan, (7) Sangat menarik bagi siswa, sehingga memungkinkan kelas menjadi dinamis dan penuh antusias, (8) Membangkitkan gairah dan semangat optimisme dalam diri siswa serta menumbuhkan rasa kebersamaan dan kesetiakawanan sosial yang tinggi, (9) Dapat menghayati peristiwa yang berlangsung dengan mudah dan dapat memetik butir-butir hikmah yang terkandung di dalamnya dengan penghayatan siswa sendiri, (1) Dimungkinkan dapat meningkatkan kemampuan profesional siswa, dan dapat menumbuhkan atau membuka kesempatan bagi lapangan.

Tri Hita Karana, berasal dari bahasa Sansekerta. Dari kata Tri yang berarti tiga, Hita berarti sejahtera dan Karana berarti penyebab. Pengertian Tri Hita Karana adalah tiga hal pokok yang menyebabkan kesejahteraan dan kemakmuran hidup manusia. Dengan demikian suatu ciri khas desa adat di Bali minimal mempunyai tiga unsur pokok, yakni : wilayah, masyarakat dan tempat suci untuk memuja Tuhan/ Sang Hyang Widhi (Wirawan, 2011:2).

Pembelajaran dengan model role playing dapat dikombinasikan dengan kegiatan-kegiatan tertentu yang melibatkan kemampuan intelektual dengan sikap dan keterampilan siswa. Suatu gambaran nyata yang ditunjukkan oleh hal tersebut dapat dilihat dengan pembelajaran role playing yang dikombinasikan dengan Tri Hita Karana. Bagian Tri Hita Karana yang pertama yaitu hubungan manusia dengan Tuhan. Hal ini dapat dibuktikan dengan pelaksanaan kegiatan persembahyangan pada masing-masing tempat suci. Bagian Tri Hita Karana kedua yaitu hubungan manusia dengan sesama manusia. Ini dapat dilihat contohnya seseorang siswa dapat menunjukkan rasa hormatnya kepada orang tua selaku guru rupaka, guru selaku guru pengajian, pemerintah sebagai guru wisesa serta dengan sesamanya dengan tingkatan usianya masing-masing. Bagian Tri Hita Karana yang ketiga yaitu hubungan manusia dengan alam sekitarnya. Ini dapat dilihat siswa dapat memelihara, melestarikan dan menciptakan alam sekitarnya agar siswa dapat menyesuaikan dirinya dengan lingkungan tempat tinggalnya.

Pembelajaran konvensional adalah pembelajaran yang biasa dilakukan oleh guru dalam kegiatan mengajar sehari-hari. Pembelajaran Konvensional sudah tidak begitu efektif lagi digunakan dalam pembelajarn sekarang, terlihat dari sebagian siswa tidak memahami materi sehingga target yang diinginkan sekolah tidak tercapai Marjan (2014).

Masalah utama dalam pembelajaran pada pendidikan formal (sekolah) dewasa ini adalah masih rendahnya daya serap peserta didik. Hal ini tampak dari rerata hasil belajar pelajar peserta didik yang senantiasa masih sangat memperihatinkan. Prestasi ini tentunya merupakan hasil kondisi pembelajaran yang masih bersifat konvensional dan tidak menyentuh ranah dimensi peserta didik itu sendiri, yaitu bagaimana sebenarnya belajar itu (belajar untuk belajar). Dalam arti yang lebih substansial, bahwa proses pembelajaran hingga dewasa ini masih memberikan akses bagi anak didik untuk berkembang secara mandiri.

Pembelajaran konvensional dalam kurikulum 2013 adalah pendekatan saintifik. Menurut Wartini (2014) pendekatan saintifik adalah pembelajaran yang mendorong siwa untuk melakukan keterampilanketerampilan ilmiah seperti mengamati, menanya, mengumpulkan informasi, mengasosiasi, dan mengkomunikasikan. Menurut (Kosasih 2014:72) pendekatan saintifik merupakan pendekatan di dalam kegiatan pembelajaran yang mengutamakan kreativitas dan temuan-temuan siswa. Pengalaman belajar yang mereka peroleh tidak bersifat indoktrinisasi, hafalan dan sejenisnya. Pengalaman belajar, baik itu yang berupa pengetahuan, keterampilan dan sikap mereka peroleh berdasarkan kesadaran dan kepentingan mereka sendiri. Berdasarkan kenyataan dilapangan dalam mengaplikasikan pendekatan saintifik guru belum mampu menerapknya dengan efisien. Guru belum mampu memvariasikan pendekatan saintifk dengan model-model pembelajaran yang ada. Sehingga dalam pembelajaran saintifik siswa merasa bosan dengan pembelajaran yang sama secara terus menerus sebagai akibatnya siswa kurang aktif dalam pembelajaran.

Sejalan dengan pendapat tersebut Sumayasa (2015) menyatakan. Pembelajaran dengan pendekatan saintifik adalah proses pembelajaran yang dirancang sedemikian rupa agar peserta didik secara aktif mengkontruk konsep, hukum dan prinsip melalui tahapan-tahapan mengamati (untuk mengidentifikasi atau menemukan masalah), merumuskan masalah atau mengajukan atau merumuskan hipotesis, mengumpulan data dengan berbagai teknik, menganalisis data, menarik kesimpulan, dan mengkomunikasikan konsep hukum atau prinsip yang ditemukan.

\section{Metode}

Tujuan penelitian ini adalah untuk mengetahui perbedaan yang signifikan kompetensi pengetahuan IPS kelompok siswa yang dibelajarkan dengan model pembelajaran role playing berbasis Tri Hita Karana dengan kelompok siswa yang dibelajarkan melalui pembelajaran konvensional pada siswa kelas IV SD 
Gugus Untung Surapati Kecamatan Denpasar Timur Tahun Pelajaran 2016/2017. Jenis penelitian ini adalah penelitian eksperimen semu dengan rencangan nonequivalent control group design (Sugiono, 2014:89). Pada penelitian ini pemberian pre test biasanya digunakan untuk mengukur equivalensi atau penyetaraan kelompok (Dantes, 2012:97). Berdasarkan hal tersebut, maka dalam penelitian ini pre test digunakan untuk menyetarakan kelompok.

Populasi dapat didefinisikan sebagai sejumlah kasus yang memenuhi seperangkat kriteria tertentu, yang ditentukan peneliti (Dantes, 2012: 37). Populasi adalah keseluruhan subjek penelitian (Arikunto, 2010:173). Menurut Ary, dkk (dalam Setyosari, 2013:221) populasi merupakan kelompok yang lebih besar jumlahnya dan biasanya yang dipakai untuk menggeneralisasikan hasil penelitian. Sedangkan menurut Sanjaya (2013:228). Populasi adalah keseluruhan yang menjadi target dalam menggeneralisasikan hasil penelitian. Sejalan dengan pendapat tersebut Sugiyono (2014:90) menyatakan, Populasi adalah wilayah generalisasi yang terdiri atas obyek atau subyek yang mempunyai kualitas dan karakteristik tertentu yang ditetapkan oleh peneliti untuk dipelajari dan kemudian ditarik kesimpulan.

Dapat dirangkum pengetian populasi adalah keseluruhan orang-orang yang memiliki karakteristik tertentu yang ingin diteliti dan dipelajari kemudian ditarik sebuah kesimpulan untuk menggeneralisasikan hasil penelitian. Populasi dalam penelitian ini adalah seluruh siswa kelas IV SD Gugus Untung Surapati Kecamatan Denpasar Timur tahun pelajaran 2016/2017, yang terdiri 14 kelas dari 10 SD. Jumlah populasi dari penelitian ini adalah 540 orang siswa.

Sampel sebagai bagian dari populasi, lebih lanjut dijelaskan bahwa sampel adalah sebagian atau wakil populasi yang diteliti (Arikunto, 2010:174). Menurut Setyosari (2015:221) sampel adalah suatu kelompok yang lebih kecil atau bagian dari populasi secara keseluruhan. Jadi dapat disimpulkan bahwa sampel adalah bagian dari populasi yang digunakan untuk memperoleh informasi yang berkaitan dengan seluruh anggota populasi. Sampel adalah "bagian dari jumlah dan karakteristik yang dimiliki oleh populasi tersebut" Sugiyono (2014:91). Menurut Dantes (2012:38), "Perwakilan populasi disebut sampel". Sedangkan menurut Agung (2014:69) sampel ialah sebagian dari populasi yang diambil, yang dianggap mewakili seluruh populasi dan diambil dengan menggunakan teknik tertentu. Sampel dalam penelitian ini adalah siswa kelas IV SDN 6 Sumerta berjumlah 39 siswa sebagai kelompok yang dibelajarankan dengan model pembelajaran role playing berbasis Tri Hita Karana dan siswa kelas IV SDN 11 Sumerta berjumlah 38 orang siswa sebagai kelompok kontrol dengan pembelajaran konvensional.

Data yang didapatkan dalam penelitian ini dilakukan dengan memberikan post test atau tes akhir pembelajaran yang dikumpulkan dengan metode tes setelah perlakuan yang diberikan kepada kelompok eksperimen dan kelompok kontrol dalam pembelajaran. Sebelum digunakan, tes tersebut terlebih dahulu divalidasi secara teoritis dengan menggunakan kisi-kisi dan dikonsultasikan pada ahli, selanjutnya dilakukan validasi secara empirik dengan jumlah responden sebanyak 39 orang. Dari hasil uji instrumen yang meliputi uji validitas, uji reliabilitas, uji daya beda, dan uji indek kesukaran diperoleh 30 butir tes yang dinyatakan layak digunakan dalam penelitian dari total 60 butir tes yang diujicobakan.

Teknik yang digunakan untuk menganalisis kompetensi pengetahuan IPS dalam penelitian ini adalah dengan menggunakan analisis statisti yaitu uji-t. Sebelum dilaksanakannya uji-t analisis terlebih dahulu dilaksanakan uji prasyarat yang meliputi uji normalitas sebaran data dan uji homogenitas varians.

\section{Hasil dan Pembahasan}

Hipotesis penelitian yang diuji dalam penelitian ini adalah hipotesis nol (H0) yang berbunyi: tidak terdapat perbedaan yang signifikan kompetensi pengetahuan IPS kelompok siswa yang dibelajarkan dengan model pembelajaran role playing berbasis Tri Hita Karana dengan kelompok siswa yang dibelajarkan melalui pembelajaran konvensional pada siswa kelas IV SD Gugus Untung Surapati Kecamatan Denpasar Timur Tahun Pelajaran 2016/2017.

Sedangkan hipotesis (Ha) alternatif yang berbunyi: terdapat perbedaan yang signifikan kompetensi pengetahuan IPS kelompok siswa yang dibelajarkan dengan model pembelajaran role playing berbasis Tri Hita Karana dengan kelompok siswa yang dibelajarkan melalui pembelajaran konvensional pada siswa kelas IV SD Gugus Untung Surapati Kecamatan Denpasar Timur Tahun Pelajaran 2016/2017.

Hasil perhitungan menunjukkan data kompetensi pengetahuan IPS Siswa Kelas IV kelompok eksperimen dengan tertinggi yang diperoleh siswa adalah 83 dan nilai terendah adalah 57 dengan angka rata-rata (mean) sebesar 84,31. Hasil perhitungan menunjukkan data kompetensi pengetahuan IPS Siswa Kelas IV kelompok kontrol dengan tertinggi yang diperoleh siswa adalah 83 dan nilai terendah adalah 57, dengan angka rata-rata (mean) sebesar 69,11.

Dari data tersebut diketahui bahwa nilai rata-rata yang diperoleh siswa yang dibelajarkan dengan model pembelajaran role playing berbasis Tri Hita Karana dengan kelompok siswa yang dibelajarkan melalui pembelajaran konvensional. 
Sebelum dilakukan pengujian hipotesis dengan analisis uji-t, terlebih dahulu harus dilakukan uji prasyarat yang meliputi uji normalitas sebaran data dan uji homogenitas varians. Uji normalitas sebaran data dimaksudkan untuk mengetahui sebaran data berdistribusi normal atau tidak.

Berdasarkan hasil analisis diperoleh harga $\chi 2$ hitung = 2,060 untuk kelompok eksperimen. Harga tersebut kemudian dikonsultasikan dengan harga $\chi 2$ tabel dengan $\mathrm{dk}=5$ dan taraf signifikansi $5 \%$ sehingga diperoleh harga $\chi 2$ tabel $=11,070$. Karena $\chi 2$ hitung $=2,060<\chi 2$ tabel $(\alpha=0,05)=11,070$ maka H0 diterima (gagal ditolak). Ini berarti sebaran data kompetensi pengetahuan IPS kelompok eksperimen berdistribusi normal. Sedangkan pada kelompok kontrol harga $\chi 2$ hitung $=2,042$. Harga tersebut kemudian dikonsultasikan dengan harga $\chi 2$ tabel dengan $\mathrm{dk}=5$ dan taraf signifikansi $5 \%$ sehingga diperoleh harga $\chi 2$ tabel $=11,070$. Karena $\chi 2$ hitung $=2,042<\chi 2$ tabel $(\alpha=0,05)=11,070$ maka H0 diterima (gagal ditolak). Ini berarti sebaran data kompetensi pengetahuan IPS kelompok kontrol berdistribusi normal.

Selanjutnya dilakukan uji homogenitas varians. Uji homogenitas data kompetensi pengetahuan IPS kelompok eksperimen dan kelompok kontrol diperoleh Fhitung $=1,47$. Nilai tersebut kemudian dikonsultasikan dengan harga Ftabel $(\alpha=0,05)=1,71$ dengan dk 37,38. Karena Fhitung $=1,47<$ Ftabel $(\alpha=0,05)=1,71$ maka dapat dikatakan data kompetensi pengetahuan IPS kelompok eksperimen dan kelompok kontrol mempunyai varians yang homogen.

Berdasarkan hasil uji normalitas sebaran data dan uji homogenitas varians dapat diketahui bahwa data yang diperoleh dari kelompok eksperimen dan kelompok kontrol berdistribusi normal dan memiliki varians yang homogen. Karena data yang diperoleh telah memenuhi uji prasyarat, maka uji hipotesis dapat.

Tabel 1. Rekapitulasi Analisis Uji-t

\begin{tabular}{llccccccc}
\hline No & \multicolumn{1}{c}{ Sampel } & $\mathrm{N}$ & $\mathrm{Dk}$ & $\mathrm{X}$ & $\mathrm{S}^{2}$ & $\mathrm{t}_{\text {hitung }}$ & $\mathrm{t}_{\text {tabel }}$ & Status \\
\hline 1 & Kelompok eksperimen & 39 & \multirow{2}{*}{75} & 84,31 & 52,150 & \multirow{2}{*}{8,315} & \multirow{2}{*}{2,000} & \multirow{2}{*}{$\mathrm{H}_{0}$ ditolak } \\
2 & Kelompok kontrol & 38 & & 69,11 & 76,737 & & & \\
\hline
\end{tabular}

Dari hasil analisis diperoleh thitung $=8,315$ dan ttabel $=2,000$ pada taraf signifikansi $5 \%(\alpha=0,05)$ dengan $\mathrm{dk}=\mathrm{n} 1+\mathrm{n} 2-2=39+38-2=75$. Oleh karena thitung $=8,315>\operatorname{ttabel}(\alpha=0,05)=2,000$ maka H0 yang menyatakan bahwa tidak terdapat perbedaan yang signifikan kompetensi pengetahuan IPS kelompok siswa yang dibelajarkan dengan model pembelajaran role playing berbasis Tri Hita Karana dengan kelompok siswa yang dibelajarkan melalui pembelajaran konvensional pada siswa kelas IV SD Gugus Untung Surapati Kecamatan Denpasar Timur Tahun Pelajaran 2016/2017 ditolak, dan berarti Ha yang menyatakan bahwa terdapat perbedaan yang signifikan kompetensi pengetahuan IPS kelompok siswa yang dibelajarkan dengan model pembelajaran role playing berbasis Tri Hita Karana dengan kelompok siswa yang dibelajarkan melalui pembelajaran konvensional pada siswa kelas IV SD Gugus Untung Surapati Kecamatan Denpasar Timur Tahun Pelajaran 2016/2017 diterima. Dapat dikatakan bahwa terdapat perbedaan yang signifikan kompetensi pengetahuan IPS antara yang dibelajarkan dengan model pembelajaran role playing berbasis Tri Hita Karana dan pembelajaran secara konvensional pada siswa kelas IV SD Gugus Untung Surapati Kecamatan Denpasar Timur Tahun Pelajaran 2016/2017.

Usia siswa kelas IV SD dalam taraf usia bermain, sehingga guru perlu menerapkan pembelajaran yang dapat menyisipkan kegiatan bermain. Penerapan pembelajaran role playing melibatkan seluruh komponen yang dimiliki oleh siswa untuk dapat menemukan suatu proses pembelajaran dalam pencapaian tujuan. Keterlibatan tersebut dapat berbentuk pengekspresian diri serta penggunaan bahasa yang baik dan benar. Pembelajaran role playing dapat menumbuhkan sikap yang antusias terhadap materi yang disajikan sehingga menimbukan kesan yang menyenangkan bagi siswa karena siswa tersebut dapat dioptimalkan kegiatannya secara fisik maupun intelektualnya.

Uraian di atas tercermin pada karakteristik kurikulum 2013 yang menyatakan bahwa usia siswa SD tidak hanya harus dibebani materi-materi yang sifatnya teoritis saja. Pengajaran perlu disisipkan hal-hal tertentu yang dapat merangsang pikiran siswa agar materi yang diajarkan dapat menarik bagi siswa. Dalam hal ini pembelajaran model role playing mempunyai peranan yang tepat untuk membangkitkan ingatan serta menanamkan pengetahuan secara efektif. Pembelajaran role playing ini mengajak siswa bermain peran melibatkan permainan siswa untuk menanamkan materi pelajaran.

Penyajian pelajaran menggunakan model role playing, seorang guru lebih menonjolkan dirinya sebagai fasilitator terhadap siswa. Guru juga dapat memberikan batasan-batasan atau aturan-aturan tertentu dalam menyajikan pelajaran yang menggunakan model ini. Sehingga memiliki kesan guru lebih menonjolkan diri dengan rasa keakraban terhadap siswa. Dari sisi lain siswa tidak merasa dirinya berhadapan dengan guru. Bahkan guru dianggap sebagai teman bermainnya. 
Pembelajaran role playing secara tidak langsung telah menumbuhkan hubungan-hubungan tertentu di antara siswa. Siswa dapat berinteraksi serta menghargai antar temannya mampu mengkondisikan tempat mereka bermain. Siswa tidak merasa ada perbedaan di antara teman bermainnya. Siswa juga dapat menghargai tempat mereka bermain sesuai dengan permaianan yang dilakukan. Terlebih dapat menghargai sesama teman yang memiliki kepercayaan yang berbeda.

Dengan menampilkan permainan yang menyerupai bentuk sebenarnya menimbulkan kesan tertentu terhadap siswa seperti ingatan yang kuat dan lama, gairah yang tinggi, unsur saling menyenangkan, memiliki rasa kebersamaan serta dapat dihayati dalam kehidupan mereka sehari-hari baik di sekolah maupun di lingkungan atau masyarakat tempat tinggal siswa tersebut.

Hasil penelitian ini memperkuat simpulan yang disampaikan oleh Sukreni (2014) yang menyatakan bahwa terdapat pengaruh model pembelajaran role playing berbasis penilaian kinerja terhadap keterampilan berbicara pada pelajaran Bahasa Indonesia siswa kelas V SD Gugus Kapten Japa Tahun Ajaran 2013/2014 dan Wardana (2014) yang menyatakan bahwa terdapat pengaruh model pembelajaran role playing terhadap keterampilan berbicara dalam pembelajaran bahasa Indonesia siswa kelas V SD Gugus II Kecamatan Karangasem Kabupaten Karangasem tahun pelajaran 2013/2014.

Dari hasil analisis diperoleh thitung $=8,315$ dan ttabel $=2,000$ pada taraf signifikansi $5 \%(\alpha=0,05)$ dengan $\mathrm{dk}=\mathrm{n} 1+\mathrm{n} 2-2=39+38-2=75$. Oleh karena thitung $=8,315>\operatorname{ttabel}(\alpha=0,05)=2,000$ maka H0 yang menyatakan bahwa tidak terdapat perbedaan yang signifikan kompetensi pengetahuan IPS kelompok siswa yang dibelajarkan dengan model pembelajaran role playing berbasis Tri Hita Karana dengan kelompok siswa yang dibelajarkan melalui pembelajaran konvensional pada siswa kelas IV SD Gugus Untung Surapati Kecamatan Denpasar Timur Tahun Pelajaran 2016/2017 ditolak, dan berarti Ha yang menyatakan bahwa terdapat perbedaan yang signifikan kompetensi pengetahuan IPS kelompok siswa yang dibelajarkan dengan model pembelajaran role playing berbasis Tri Hita Karana dengan kelompok siswa yang dibelajarkan melalui pembelajaran konvensional pada siswa kelas IV SD Gugus Untung Surapati Kecamatan Denpasar Timur Tahun Pelajaran 2016/2017 diterima. Dapat dikatakan bahwa terdapat perbedaan yang signifikan kompetensi pengetahuan IPS antara yang dibelajarkan dengan model pembelajaran role playing berbasis Tri Hita Karana dan pembelajaran secara konvensional pada siswa kelas IV SD Gugus Untung Surapati Kecamatan Denpasar Timur Tahun Pelajaran 2016/2017.

Usia siswa kelas IV SD dalam taraf usia bermain, sehingga guru perlu menerapkan pembelajaran yang dapat menyisipkan kegiatan bermain. Penerapan pembelajaran role playing melibatkan seluruh komponen yang dimiliki oleh siswa untuk dapat menemukan suatu proses pembelajaran dalam pencapaian tujuan. Keterlibatan tersebut dapat berbentuk pengekspresian diri serta penggunaan bahasa yang baik dan benar. Pembelajaran role playing dapat menumbuhkan sikap yang antusias terhadap materi yang disajikan sehingga menimbukan kesan yang menyenangkan bagi siswa karena siswa tersebut dapat dioptimalkan kegiatannya secara fisik maupun intelektualnya.

Uraian di atas tercermin pada karakteristik kurikulum 2013 yang menyatakan bahwa usia siswa SD tidak hanya harus dibebani materi-materi yang sifatnya teoritis saja. Pengajaran perlu disisipkan hal-hal tertentu yang dapat merangsang pikiran siswa agar materi yang diajarkan dapat menarik bagi siswa. Dalam hal ini pembelajaran model role playing mempunyai peranan yang tepat untuk membangkitkan ingatan serta menanamkan pengetahuan secara efektif. Pembelajaran role playing ini mengajak siswa bermain peran melibatkan permainan siswa untuk menanamkan materi pelajaran.

Penyajian pelajaran menggunakan model role playing, seorang guru lebih menonjolkan dirinya sebagai fasilitator terhadap siswa. Guru juga dapat memberikan batasan-batasan atau aturan-aturan tertentu dalam menyajikan pelajaran yang menggunakan model ini. Sehingga memiliki kesan guru lebih menonjolkan diri dengan rasa keakraban terhadap siswa. Dari sisi lain siswa tidak merasa dirinya berhadapan dengan guru. Bahkan guru dianggap sebagai teman bermainnya.

Pembelajaran role playing secara tidak langsung telah menumbuhkan hubungan-hubungan tertentu di antara siswa. Siswa dapat berinteraksi serta menghargai antar temannya mampu mengkondisikan tempat mereka bermain. Siswa tidak merasa ada perbedaan di antara teman bermainnya. Siswa juga dapat menghargai tempat mereka bermain sesuai dengan permaianan yang dilakukan. Terlebih dapat menghargai sesama teman yang memiliki kepercayaan yang berbeda.

Dengan menampilkan permainan yang menyerupai bentuk sebenarnya menimbulkan kesan tertentu terhadap siswa seperti ingatan yang kuat dan lama, gairah yang tinggi, unsur saling menyenangkan, memiliki rasa kebersamaan serta dapat dihayati dalam kehidupan mereka sehari-hari baik di sekolah maupun di lingkungan atau masyarakat tempat tinggal siswa tersebut. Hasil penelitian ini memperkuat simpulan yang disampaikan oleh Sukreni (2014) yang menyatakan bahwa terdapat pengaruh model pembelajaran role playing berbasis penilaian kinerja terhadap keterampilan berbicara pada pelajaran Bahasa Indonesia siswa kelas V SD Gugus Kapten Japa Tahun Ajaran 2013/2014 dan Wardana (2014) yang menyatakan bahwa terdapat pengaruh model pembelajaran role playing terhadap 
keterampilan berbicara dalam pembelajaran bahasa Indonesia siswa kelas V SD Gugus II Kecamatan Karangasem Kabupaten Karangasem tahun pelajaran 2013/2014.

\section{Simpulan dan saran}

Berdasarkan hasil penelitian yang diperoleh bahwa terdapat perbedaan yang signifikan kompetensi pengetahuan IPS kelompok siswa yang dibelajarkan dengan model pembelajaran role playing berbasis Tri Hita Karana dengan kelompok siswa yang dibelajarkan melalui pembelajaran konvensional pada siswa kelas IV SD Gugus Untung Surapati Kecamatan Denpasar Timur Tahun Pelajaran 2016/2017, dengan nilai thitung sebesar 8,315 dan t-tabel 2,000 dengan taraf signifikansi 5\% dan derajat kebebasan 75 . Dengan demikian model pembelajaran role playing berbasis Tri Hita Karana berpengaruh terhadap kompetensi pengetahuan IPS siswa kelas IV SD Gugus Untung Surapati Kecamatan Denpasara Timur Tahun Pelajaran 2016/2017.

Adapun saran yang ingin disampaikan melalui penelitian ini yaitu (1) Kepada guru-guru hendaknya dapat menggunakan model pembelajaran role playing berbasis Tri Hita Karana sebagai salah satu alternatif dalam pembelajaran karena model ini berpengaruh terhadap kompetensi pengetahuan IPS. (2) Kepada sekolah hendaknya memfasilitasi terlaksananya model pembelajaran role playing berbasis Tri Hita Karana untuk menunjang pembelajaran agar siswa semakin termotivasi untuk belajar dan memanfaatkan fasilitas tersebut untuk mengoptimalkan hasil belajar siswa sehingga mutu sekolah menjadi meningkat. (3) Kepada peneliti lain hendaknya hasil penelitian ini dapat dijadikan kajian penelitian relevan. Sebagai penunjang penelitian dengan kajian yang lebih luas dan mendalam mengenai model pembelajaran role playing berbasis Tri Hita Karana dalam kaitannya dengan hasil belajar baik kompetensi pengetahuan, sikap, maupun keterampilan.

\section{Daftar Rujukan}

Agung, A.A Gede. 2014. Metodologi Penelitian Pendidikan. Singaraja: Aditya Media Publishing.

Arikunto, Suharsimi. 2010. Prosedur Penelitian. Jakarta: PT Rineka Cipta.

Dantes, Nyoman. 2012. Metode Penelitian. Yogyakarta: CV Andi Offset.

Depdiknas. 2006. Badan Standar Nasional Pendidikan (BNSP) Untuk Satuan Pendidikan Dasar. Jakarta. Depdiknas.

Huda, Miftahul. 2015. Model-Model Pengajaran Dan Pembelajaran. Yogyakarta: Pustaka Pelajar.

Kosasih. 2014. Strategi Belajar dan Pembelajaran Implementasi Kurikulum 2013. Bandung: Yrama Widya.

Kurniasih, Imas dan Berlin Sani. 2015. Model Pembelajaran. Kata Pena CV Solusi Distribusi

Marjan, Johari. 2014. "Pengaruh Pendekatan Saintifik Terhadap Hasil Belajar Biologi Dan Keterampilan Proses Sains Siswa Ma Mu'allimat Nw Pancor Selong Kabupaten Lombok Timur Nusa Tenggara Barat". Jurnal Pendidikan dan Pengajaran. Volume 4 Edisi Mei, (hlm.1-12)

Sanjaya, Wina. 2013. Penelitian Pendidikan Jenis, Metode, dan Prosedur. Jakarta : Kencana Prenada Media Group.

Setyosari, Punaji. 2013. Metode Penelitian Pendidikan dan Pengembangan. Jakarta: Kencana Prenada Media Group.

Setyosari, Punaji. 2015. Metode Penelitian Pendidikan dan Pengembangan. Jakarta: Kencana Prenada Media Group.

Suastra, I Wayan. 2013. Model Pembelajaran Fisika Untuk Mengembangkan Kreativitas Berpikir Dan Karakter Bangsa Berbasis Kearifan Lokal Bali Jurnal Pendidikan Indonesia Vol. 2, No. 2, Oktober 2013

Sugiyono. 2014. Metode Penelitian Kuantitatif Kualitatif Dan R\&D. Bandung : Alfabeta.

Sukreni, Ni Nyoman. 2014. "Pengaruh Model Pembelajaran Role Playing Berbasis.

Sumayasa, Nyoman. 2015. "Pengaruh Implementasi Pendekatan Saintifik Terhadap Motivasi Belajar Dan Hasil Belajar Bahasa Indonesia Pada Siswa Kelas VI Di Sekolah Dasar Se Gugus VI Kecamatan Abang, Karangasem" Jurnal Pendidikan Dan Pengajaran. Volume 5, (hlm.1-6) 
Undang-Undang Republik Indonesia No. 20 Tahun 2003 tentang Sistem Pendidikan Nasional. 2003. Jakarta.

Wartini, Ida Ayu Km Mirah. 2014. "Pengaruh Implementasi Pendekatan Saintifik Terhadap Sikap Sosial Dan Hasil Belajar PKn Di Kelas VI SD Jemabatan Budaya, Kuta" Jurnal Pendidikan dan Pengajaran. Volume 4, (hlm.1-11).

Wirawan, Adi. 2011. Tri Hita Karana. Denpasar : Paramita. Penilaian Kinerja Terhadap Keterampilan Berbicara Pada Pelajaran Bahasa Indonesia Siswa Kelas V SD". Jurnal Pendidikan dan Pengajaran. Volume 2, Nomor 1, (hal. 1-10) 